\title{
The Study of the Conflicts between the European Union (Regional Economies) and the World Trade Organization
}

\author{
Huang Xian Yu
}

\begin{abstract}
Individual European Union (EU) members and EU as a whole both join the World Trade Organization (WTO) giving rise to a number of problems including whether there exists double membership in the WTO, the obligations of EU when its Members States breach WTO Agreements. This paper aims to explore some of these problems and further extend the study to some conflicts between regional economies and WTO.
\end{abstract}

Index Terms-EU, WTO, double membership, conflicts, regional economies

\section{INTRODUCTION}

After the establishment of the European Community (EC), it has created a wide range of external relations with non-member states through bilateral and multilateral agreements. The WTO Agreement is one of these agreements which were jointly concluded by the EC and its Member States. Since both the EC and its Member States are members of WTO, this lead to double or mixed memberships in WTO. The double membership was arise from historical evolution and practical necessity and led to a number of problems including disputes of double membership by EC in the WTO, the obligations of EC when its Member States breach WTO Agreements, the applicability of the WTO rules on EC laws and the effects and the effectiveness of WTO laws and decisions on EC. This paper aims to explore these problems and conclude some of the major conflicts between EC and WTO. The paper further extends the study to some conflicts between Regional Economies and WTO.

\section{EU'S DOUBLE MEMBERSHIPS IN THE WTO - HISTORY}

In and around 1947, only some of the Member States of EC were contracting parties of General Agreement on Tariffs and Trade (GATT). After the establishment of the EC, EC was engaged in the negotiation of the GATT / WTO including the Uruguay Round. GATT framework negotiated including accession protocols and trade agreements were then accepted by WTO members including EC and its Member States.

Since the 1960s, all GATT contracting parties have accepted such exercise of rights and fulfillment of obligations by the EC and have asserted their own GATT rights including dispute settlement proceedings relating to measures of individual Member States of EC. The EC has replaced its Member States as bearers of rights and obligations under the GATT. Although EC is a full member of the WTO

Manuscript received March 15, 2013; revised May 5, 2013.

X. Y. Huang is with the Chu Hai College of Higher Education, Hong Kong (e-mail: jasminehuang@chuhai.edu.hk). representing all the 27 Membership States' interests, its competence is restricted to trade policy under Article 133 $\mathrm{EC}^{1}$.

Since 1970, most agreements negotiated in the framework of GATT were accepted by the EC alone without acceptance by EC Member States ${ }^{2}$. The EC exercised all rights and fulfilled almost all obligations under GATT laws in its own name like a GATT contracting party.

In 1994, WTO was established. The European Court of Justice (ECJ) concluded that EC is exclusively competent in the area of trade in goods, cross-frontier services and specific parts of the Agreement on Trade-Related Aspects of Intellectual Property Rights (TRIPS) ${ }^{3}$. The EC, however, shares powers with the Member States in other services and areas of intellectual property. To ensure unity on conduct towards third countries and the WTO, the EC and its Member States have duties, according to Article 10 EC, to co-operate in these areas that do not fall under the exclusive competence of the EC. It is therefore practical and necessary that EU and the Member States are both members of $\mathrm{WTO}^{4}$

\section{LEGAL BASIS OF EU IN WTO MEMBERSHIP}

Under the WTO Agreement, the membership does not only include States but also separate custom territories possessing full autonomy in the conduct of their external commercial relations and in the other matters covered by the WTO Agreement.

The EU is also a WTO member which is specifically provided for in the WTO Agreement ${ }^{5}$. Under Article XI of the WTO Agreement, the EU and its Member States became original members to the WTO of their own right. This reflects the division of competence between the EU and the Member States in the various areas covered by the WTO Agreement such as trades in goods, trade in services, and the protection of intellectual property rights ${ }^{6}[1]$. Irrespective of the internal division of competence between the EU and its Member States, they can all be held responsible for compliance with all the obligations under the WTO Agreement ${ }^{7}[1]$.

\footnotetext{
${ }^{1}$ Para. 6 of Art. 133 EC

${ }^{2}$ The only exceptions are two agreements at the end of Tokyo Round of multilateral trade negotiation and the part of the Tariff Protocol relating to ECSC products. Jacques H.J. Bourgeois, The Tokyo Round Agreements on Technical Barriers and on Government Procurement in International EEC Perspective, 19 Common Mkt. L. Rev, 21-22 (1982)

${ }^{3}$ Opinion 1/94 ECR I-5267

${ }^{4}$ Para 108 Opinion $1 / 94$

${ }_{6}^{5}$ Art XI WTO Agreement

${ }^{6}$ Peter Van den Bossche, The Law and Policy of the World Trade Organization - Text, Cases and Materials, Cambridge University Press, pp.105

${ }^{7}$ Ibid. p.106
} 
The ECJ has confirmed, in its Opinion 1/94, that the Community has exclusive competence on the basis of Article 113 to conclude multilateral agreements relating to trade in goods, i.e. those taken up in Annex 1A to the WTO Agreement. It is the result of the complete transfer of competence from the Member States to the Community. When exclusive competence arises, the Member States are considered to have forfeited their legislative power in that field. In other words, the exercise of concurrent power by Member States in the area covered by the Community's exclusive competence is impossible ${ }^{8}[2]$. However, Member States still have competences in services and intellectual property rights as confirmed in ECJ's Opinion $1 / 94^{9}$ on the joint competence of the Community for the conclusion of agreements in relation to the WTO Agreement.

Under international law a body can act effectively only if it possesses legal personality ${ }^{10}[3]$. The EC can consequently be bounded by the WTO Agreement only if it possesses such personality. Legal personality was traditionally thought to be owned only by sovereign states, but is also now recognized to be held by international organizations ${ }^{11}[4]$. The EC is an international organization, founded by its Member States in 1957, and thereafter transformed and amended by means of various treaties. There is no doubt that the EC possesses legal personality. Besides, EC must have unlimited legal personality (though unquestionably limited competences), and is therefore in principle able to bind itself to all provisions of the WTO Agreement, albeit that this may be ultra vires on the EC's internal level ${ }^{12}[5]$. Due to the lack of any competence clause in the WTO Agreement, the EC is bounded by all provisions of the WTO's Agreement.

\section{ROLE OF GATT / WTO RULES IN EU LAWS}

The traditional position of GATT / WTO rules in EU laws is that both GATT / WTO rules do not have direct effect in the EC legal system and are not in principle, among the rules in light of which the EC Court is, to review the legality of measures adopted by the Community ${ }^{13}[6]$. There are two main reasons for denying direct effect of the GATT / WTO rules. Firstly, the GATT / WTO rules have been considered being instruments of negotiation, rather than adjudication; and secondly, the GATT / WTO rules are not precise enough for the purpose of direct effect ${ }^{14}[7]$. This has been fully

\footnotetext{
${ }^{8}$ Rafael Leal-Arcas, "Polycephalous Anatomy of the EC in the WTO: An Analysis of Law and Practice”, 19 Florida Journal of International Law 569, pp. 606, 2007.

${ }^{9}$ ECJ Opinion 1/94. ECR 1994 I-5267 para.35

${ }^{10}$ R.K. Gardiner, International Law, pp.212, 2003.

${ }^{11}$ J. Klabbers, An Introduction to International Institutional Law. pp. 42, 2002.

${ }^{12}$ Eva Steinberger, 'The WTO Treaty as a Mixed Agreement: Problems with the EC's and the EC Member States' Membership of the WTO, 17 European Journal of International Law 837, pp.843, 2006.

${ }^{13}$ Gianni Fabrozio Di and Antonni Renato, "DBS Decisions and Direct Effect of WTO Law: Should the EC Courts be More Flexible when the Flexibility of the WTO System has Come to an End?" Journal of World Trade 40(4): 777-793, 2006.

${ }^{14}$ Cottier and Schefer, "The Relationship between World Trade Organization Law, National and Regional Law” Journal of International Economic Law 1, pp.10, 1998.
}

demonstrated in the Portugal v Council ${ }^{15}$ case. However, the EC Courts have identified two exceptions. Namely, where the Community intended to implement a particular obligation assumed in the context of the GATT/WTO ${ }^{16}$, or where a Community measures refers expressly to precise provision of the GATT/WTO ${ }^{17}$. Another problem of GATT / WTO rules is that since they are mainly based on the ground of negotiations, which can be changed when circumstances change, and hence flexible in nature ${ }^{18}$. This flexible nature of GATT / WTO rules reduces recognitions in EC and EC laws. However, the GATT / WTO rules have a significant effect on Germany where the WTO Agreement overlaps with the EU jurisdiction and the related trade agreement in the implementation of EC laws. Some German courts have challenged the conformity of EU laws with the WTO rules in enforcing EU laws ${ }^{19}$, and have repeatedly made reference for a preliminary ruling to the $\mathrm{ECJ}^{20}[8]$.

It is still unclear whether the same conclusion (that both GATT / WTO rules have no direct effect on EU legal system) is equally applicable when Rulings adopted by the Panel or Appellate Body of the WTO Dispute Settlement Body $(\mathrm{DSB})^{21}[9]$. In the Biret ${ }^{22}$ cases, the opinion of Advocate General Alber brought up some strong arguments in favor of granting effect to WTO rules when the DSB has already adopted a decision. He states that a ruling of the DSB removes the margin of manoeuvre of WTO contracting parties, with the obligation being to implement the findings of the DSB immediately and without conditions. This, therefore, alters the nature of the obligation of the WTO Member States, as there is, after a DSB ruling, an 'obligation sufficiently clear and precise ${ }^{23}$. These arguments relate to the new features of the WTO system, compared to the previous GATT 1947, and thus seem to plead in favor of direct effect of WTO rules in general $^{24}[10]$. However, the ECJ ruled that the damages allegedly suffered by the applicant had occurred will before the expiry of the reasonable period set by the DSB for the EC to comply with its WTO obligations, so it did not have to rule further on the matter.

AG Alber's view was followed by AG Tizzano in the Van Parys case ${ }^{25}$. He had rejected the argument of reciprocity and

\footnotetext{
${ }^{15}$ Case C-149/96, ECR I-8395 para. 47, 1999

${ }^{16}$ Nakajima exception Case C-69/89 Nakajima All Precision Co. Ltd. v Council, ECR I-2069, para. 31, 1991.

${ }^{17}$ Fediol exception Case C-70/87 Federation de l'industrie de l'huilerie de la CEE (Fediol) v Commission [1989] ECR 1781, para. 19-22.

${ }^{18}$ In the International Fruit case(Cases 21 to 24/72, , [1972] ECR 1219 para.21) the ECJ relied in essence on the preamble of GATT 1947, which stated that this agreement was based 'on the principle of negotiations undertaken on the basis of reciprocal and mutually advantageous arrangements'

${ }^{19}$ OGT Fruchthandelsgesellschaft, C-307/99 P, ECR2001, I-3159; Atlanta C-104/97 P, ECR 1999, I-6983

${ }^{20}$ Peter-Tobias Stoll, Frank Schorkopf WTO-World Economic Order, World

Trade Law, Martinus Nijhoff Publishers, pp.234, 2006.

${ }^{21}$ Greet A, Zonnekeyn, "EC Liability for Non-implementation of WTO Dispute Settlement Decisions - Are the Dice Cast?" Journal of International Economic Law 7(2), 483, pp.484, 2004.

${ }^{22}$ Case 93/02 P Biret International Sa v Council. [2003] ECR I-10497.

${ }^{23}$ Para. 89 of the opinion.

${ }^{24}$ Delphine De Mey, Pab Ibanez Colomo "Recent Developments on the Invocability of WTO Law in the EC: A Wave of Mutilation" European Foreign Affairs Review 11: 63-86 2006

${ }^{25}$ Van Parys [2005] ECR I-1465
} 
recognized the binding effect of DSB decisions ${ }^{26}$ [11]. However, the ECJ of the case took a conservative approach based on the Portugal doctrine and in light of the Nakajima and Fediol exceptions. It denied to the right to plead before a court of a Member State that Community legislation is incompatible with certain WTO rules, even if the DSB has stated that legislation is incompatible with those rules.

In the case of Ikea ${ }^{27}$, the Panel and Appellate Body of DSB held that the practice of zeroing ${ }^{28}$ applied by the Community was incompatible with Art. 2.2.2 of the Anti-Dumping Agreement contained in GATT/WTO rules. However, the ECJ used a conservative approach and held that the WTO agreements are not in principles among the rules in the light of which the Court is to review the legality of measures adopted by the Community institutions. It was commented by scholar Enrico De Angelis that it is a demonstration of the importation of the "indirect effects" of WTO laws and decisions on EC legal orders than a clear and definitive opening to the granting of direct effects to DSB ruling ${ }^{29}[12]$.

However, in the recent FIAMM ${ }^{30}$ case, the ECJ expressly denied what was recognized in the Biret case - explicitly by AG Alber and implicitly by the court. It held that a ruling of the DSB finding that the substantive rules contained in the WTO agreements have not been complied with is no more capable than those rules of conferring upon individuals a right to rely thereon before the Community courts for the purpose of having the legality at the conduct of the Community institutions reviewed. The decision was criticized by scholars that the case does not mark the ultimate position of the court on the effects to be granted to DSB's rulings and that the reasoning was not convincing as it did not address the key questions of compatibility of the position of WTO with other international agreements and with Art. 300(7) of the EC Treaty $^{31}[12]$.

\section{FURTHER CONFLICTS BETWEEN REGIONAL AND GLOBAL ECONOMIC INTEGRATIONS}

Besides the above, there are further conflicts between regional trade integrations in the form of customs and free trade areas and interim agreements and global economic integrations and WTO.

\section{A. Conflicts on the Scope of Article XXIV GATT 1994s}

The question of whether Regional Trade Arrangement (RTA) and Custom Unions (CU) are in conformity with the

\footnotetext{
${ }^{26}$ Delphine De Mey "The Effect of WTO Dispute Settlement Rulings n the EC Legl Order: Reviewing Van Parys v Belgische Internentie-en Restitutieburea", German Law Journal Vol, 6 No. 6, pp.1026, 2006.

${ }^{27}$ Ikea Wholesale Ltd. v Customs and Excise Commissioners (C351/04), ECJ I-7723, pp.69, 2007.

${ }^{28}$ Payment of Anti-dumping duties collected in force of a EC Regulation.

${ }^{29}$ Enrico De Angelis, "Effect of WTO Law and Rulings into the EC Domestic Legal Order - A Critical Review of the Most Recent Developments of the ECJ Case-law: Part 2", International Trade Law and Regulation ,15(4), pp. 137, 2009.

${ }^{30}$ Fabbrica Italiana Accumlatori Motocarri Montecchio SpA v Council of European Union (C-120/06) Unreported September 92008 (ECJ).

${ }^{31}$ Enrico De Angelis, "Effect of WTO Law and Rulings into t he EC Domestic Legal Order - A Critical Review of the Most Recent Developments of the ECJ Case-law: Part 2", International Trade Law and Regulation, 15(4), pp.144, 2009.
}

principles of the WTO has long been debated among scholars. RTA/CU have been criticized as violating the major WTO principles of the most-favored-nation treatment. However, under the old GATT, the exception to the most-favored-nation treatment did already exist, namely Art. XXIV GATT. According to paragraph 4 of this provision, in principle, that regional trade integration in the form of customs and free trade areas and interim agreements, which lead to such an RTA, can contribute to an increase in the freedom of trade and can even facilitate it in the constituent territories if certain preconditions are met.

However, neither the GATT dispute settlement system nor the WTO has fully articulated the precise limit of the Article. It was not until 1994 in the Uruguay Round that this problem became partly cured by the Dispute Settlement Understanding $^{32}$ which states as follows:

The provisions of Articles XXII and XXIII of GATT 1994 as elaborated and applied by the Dispute Settlement Understanding may be invoked with respect to any matters arising from the application of those provisions of Article XXIV relating to customs unions, free-trade areas or interim agreements leading to the formation of a customs union or free-trade area.

But there were still uncertainties on the scope of Article XXIV. In the case of Turkey - Textile ${ }^{33}$, the Appellate Body held that Article XXIV GATT 1994 could be invoked as defence to what would be otherwise a violation of other GATT/WTO provision only under very limited circumstances. The Member invoking the exception must demonstrate that the RTA is legal under sub-sections 5(a) and 8(a) of Article XXIV and that the measure was necessary to the formation of the RTA. The 'necessary' defence added as pre-requisite under GATT/WTO system is problematic. It is also unclear as to the Article XXIV defence for measures undertaken after the formation of the custom union is applicable ${ }^{34}[13]$.

\section{B. Conflicts between WTO and RTA Dispute Settlement Mechanism}

Under the present situation, it is possible that the DSB and the RTA exercise concurrent jurisdictions on disputes in which the parties are both Member States of WTO and the relevant RTA. Lawyers can find ways of framing disputes in such a manner as to permit parallel actions both in the WTO and within the RTA mechanisms, thereby evading choice of forum requirements in the RTA provisions and giving these States two bites of the apple. In a case involved with Canadian softwood lumber exports to US in which both states of members of WTO and North American Free Trade Agreement (NAFTA), there were numerous challenges from private 'interested parties' on antidumping, countervailing duty, injury and administrative review decisions relating to lumbers have been lodged under Chapter 19 of NAFTA. Simultaneously, Canada initiated a series of WTO actions against the U.S. They involved the same administrative

\footnotetext{
${ }^{32}$ Paragraph 12 Uruguay Round Understanding on the Interpretation of Article XXIV of the GATT, 1994.

${ }^{33}$ Turkey- Restrictions on Imports of Textile and Clothing Products WT/DS/34/AB/R 22.10.1999.

${ }^{34}$ David A. Gantz, Regional Trade Agreement, in The Oxford Handbook of International Trade Law, eds Daniel Bethlehem [et al.], Oxford University Press, pp. 261, 2009.
} 
decisions but engaged a different body of law, NAFTA bi-national panels and WTO panels / Appellate Body reached different conclusions on the same administrative determinations.

\section{CONCLUSION}

The legal consequences of conflicts between the operation of any RTA dispute settlement system and that of the WTO are far from clear. The evolution of RTAs and the WTO's jurisprudence on their consistencies are not yet at the stage of maturity where we can make any more than highly speculative conclusions as to how best deal with a RTA trade countermeasure that breaches WTO rules. The complex area of regime interaction raises many legal policy questions and leaves the majority of them unresolved. It is hoped that this article will be used as reference for drafting RTAs on how dispute settlement and enforcement systems might interact with the WTO's in the future. Thoughts might be extended to the WTO structure on the kind of tests that should be developed and on whether it is time for WTO Members to agree on a more systematic approach to RTA dispute settlement mechanism and their operations within the WTO context.

\section{REFERENCES}

[1] P. V. D. Bossche, The Law and Policy of the World Trade Organization - Text, Cases and Materials, Cambridge University Press, 2008, pp. 10.

[2] L. A. Rafael, "Polycephalous Anatomy of the EC in the WTO: An Analysis of Law and Practice," Florida Journal of International Law, vol. 19, pp. 569-606, 2007.

[3] R. K. Gardiner, International Law, Longman, 2003, pp. 212.

[4] J. Klabbers, An Introduction to International Institutional Law Cambridge University Press, 2002, pp. 42.

[5] E. Steinberger, "The WTO Treaty as a Mixed Agreement: Problems with the EC's and the EC Member States' Membership of the WTO,' European Journal of International Law, vol. 17, pp. 837-843, 2006.
[6] F. D. Gianni and R. Antonni, "DBS Decisions and Direct Effect of WTO Law: Should the EC Courts be More Flexible when the Flexibility of the WTO System has come to an End?" Journal of World Trade, vol. 40, no. 4, pp. 777-793, 2006.

[7] Cottier and Schefer, "The Relationship between World Trade Organization Law, National and Regional Law," Journal of International Economic Law 1, pp. 10, 1998.

[8] P. T. Stoll and F. Schorkopf, "WTO-World Economic Order," World Trade Law, Martinus Nijhoff Publishers, 2006, pp. 234.

[9] G. A. Zonnekeyn, "EC Liability for Non-implementation of WTO Dispute Settlement Decisions - Are the Dice Cast?" Journal of International Economic Law, vol. 7, no. 2, pp. 483, 2004.

[10] D. D. Mey and P. L. Colomo, "Recent Developments on the Invocability of WTO Law in the EC: A Wave of Mutilation," European Foreign Affairs Review, vol. 11, pp. 63-86, 2006.

[11] D. D. Mey, "The Effect of WTO Dispute Settlement Rulings n the EC Legal Order: Reviewing Van Parys v Belgische Interventie-en Restitutieburea," German Law Journal, vol. 6, pp. 1025-1032, 2005

[12] E. D. Angelis, "Effect of WTO Law and Rulings into the EC Domestic Legal Order - A Critical Review of the Most Recent Developments of the ECJ Case-law: Part 2," International Trade Law and Regulation, vol. 15, no. 4, pp. 144, 2009.

[13] D. A. Gantz, "Regional Trade Agreement," in The Oxford handbook of International Trade Law, eds Daniel Bethlehem et al., Oxford University Press, pp. 261, 2009.

Huang Xian Yu is senior member of IEDRC. She holds Bachelor Degree in Economics from National University of Singapore in 1985, Master of Business Administration Degree from Heriot-Watt University, UK in 1993 and $\mathrm{PhD}$ Degree from the University of Hong Kong in Economics in 2000. She also holds qualifications in Law and a number of professional qualifications in Finance. After her first degree, she worked as treasury dealer in investment banks involving researches and tradings in treasury products in Singapore. Thereafter, she worked as Assistant Professor and Associate Professor in Universities and tertiary institutions in Hong Kong and Macao involving teaching, research, programme design and development, validations and accreditation activities for the past 22 years. Currently she is an Associate Professor with Chu Hai College of Higher Education, Hong Kong.

Dr Huang is a fellow member of American Academy of Financial Management and a member of Singapore Economic Society. She has been active in research and had many publications in the fields of Economics, Finance, Trade and Investment Law. 